\title{
Innovative Practice and Development Thinking of Space Re-design in the Liaoning Provincial Library
}

\author{
Xiaowen Wang, Liaoning Provincial Cultural Performing Arts Group (Liaoning Provincial Public Cultural Service Center), \\ Shenyang, China \\ Tianni Wang, Liaoning Provincial Cultural Performing Arts Group (Liaoning Provincial Public Cultural Service Center), \\ Shenyang, China
}

\begin{abstract}
The Liaoning Provincial Library is one of the largest and most well-functional libraries. It has the largest building area and provides abundant services to the public. The Liaoning Provincial Library mainly provides readers with reading, learning, activities, innovative space services, offers creative spaces, studios, and other service spaces. In the past two years, over 4 million visited the library, and the library has held more than 2,500 activities, and has gained new experience in areas such as service philosophies, service contents, service strategies, and service guarantees. In the future, the authors still need to figure out how to integrate the interactions of multi-space usages inside and outside the library, how to express and transmit the multiple attributes and innovative areas of the public library, how to balance between organizational functions and government functions, and how to achieve the function of creative incubation using thinking and exploration practices.
\end{abstract}

\section{KEYWORDS}

China Public Library, Liaoning Provincial Library, Space Redesign, Space Service

\section{INTRODUCTION}

Liaoning Province is the only coastal province in the northeastern region of China. It is also one of the most important provinces in China, an important heavy industrial base in China, and an advance province of education and agriculture. The province is a relatively all-around developed province in China. Shenyang is in the south region of northeastern China, and it sits in the center of the Northeast Asian Economic Circle and the Bohai Sea Economic Circle. Shenyang is the capital city of the Liaoning Province, a provincial city of China (People's Forum, 2017), and also an important metropolitan area in northeastern China with an advanced equipment manufacturing base. It is also famous for its rich culture and national history (Administration of the State Council of the People 's Republic of China, 2017). The city has 10 districts, 2 counties, and is the escrow of a county-level city. The city's total area is more than 12,948 square kilometers, their urban area is 3,495 square kilometers, there is a population of 8 million 292 thousand people as of 2016 , a household population 
of 7 million 344 thousand, and is worth 546 billion-yuan with a disposable income of 39,135 yuan per capita, ranking first in the province (Shenyang Municipal Bureau of Statistics, 2016) (Figure 1).

Located in Shenyang, the Liaoning Provincial library has the most complete service functions of a public library. It is also Shenyang's and the province of Liaoning's most important public cultural service. Newly relocated to Shenyang City's new district of Hunnan, this provincial library had a trial opening to the community on August 22, 2015 and officially opened on April 23, 2017. It is the first provincial library with a modular design in China. From the bird's eye view, the library is in the shape of the letter "E" which represents an open book meaning "opening books will give you knowledge". On the one hand, the Liaoning Provincial library's construction land is 83,200 square meters and the total building area is 103,150 square meters. It is one of the largest provincial public libraries in China. With the magnificent appearance and rich connotation, the library has become beautiful scenery for the city (Wang \& Wang, 2017). The Liaoning Provincial library not only provides reading spaces, learning space services to fulfill the responsibility of providing cultural communication and social educational functions, it also provides innovative space, and active space services to help meet the needs of readers and social developments. This library has become a model of China's public library space recycling and has caught the attention of communities and industries.

At present, the Liaoning Provincial library is mainly equipped with a children's world, special group service area, exhibition hall, multi-function lecture hall, universal learning center, multimedia service area, creative space, audio room, recording room, studio room, a Chinese and foreign literature borrowing area, historical literature reading area, information consultation service area, local literature service area, and many other service spaces. It has carried out a series of activities such as parent-child reading, film appreciations, audio book listening, play watching, classics recitations, intergenerational reading, salons, AR (augmented reality) experiences, and other activities or services that give full play to the library as a key role in the popularization of scientific and cultural knowledge, enhancement of the quality of civic civilizations, and promoting social development and progress.

Figure 1. Liaoning Provincial Library

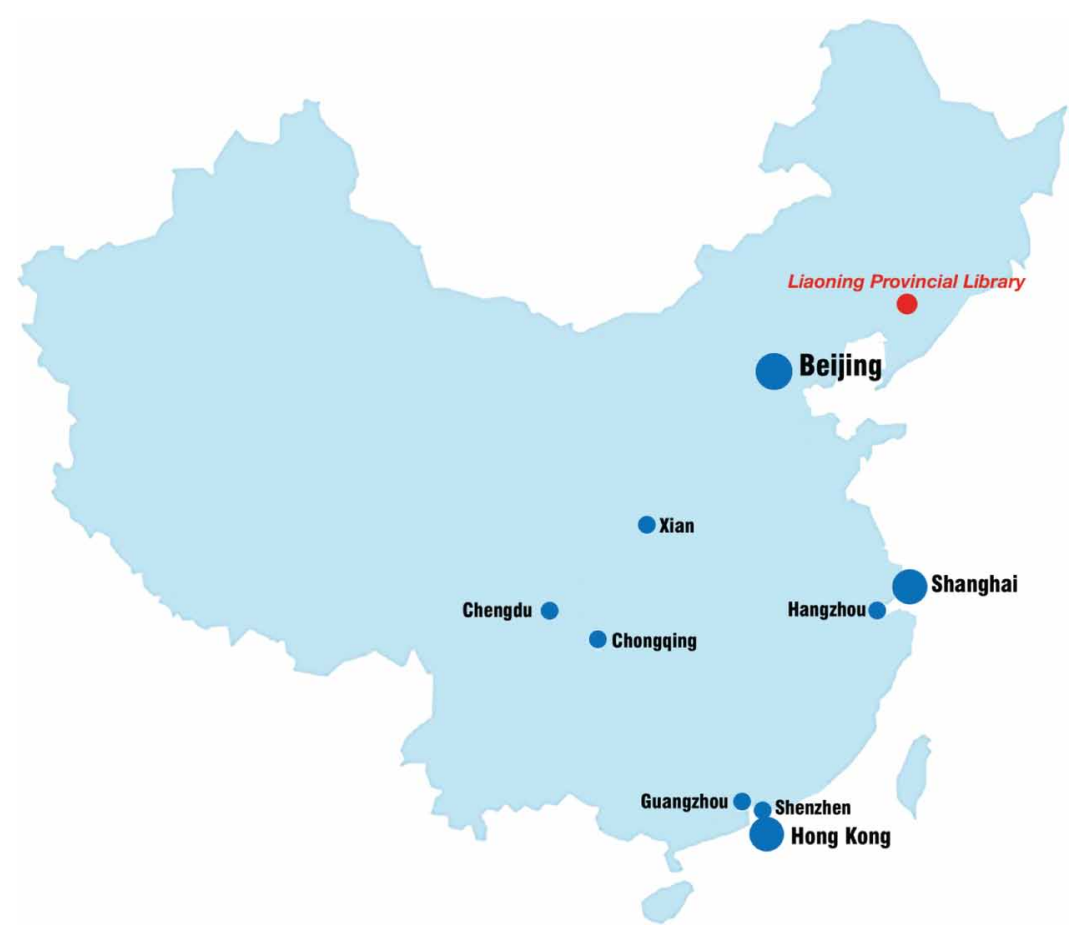




\section{PRACTICAL EXPLORATION OF SPACE RECYCLING IN THE LIAONING PROVINCIAL LIBRARY}

Over the years, the Liaoning Provincial Library has upheld the "innovation, sharing, open, equal" concept, to provide readers with professional, high quality and efficient services. The Liaoning Provincial Library has been gradually opening different sections of the library as of August 22, 2015 and officially opened as of April 23, 2017. This library has provided readers with lots of reading, learning, activities, innovative service spaces, creative spaces, studios, and other service spaces. These services have attracted the readers' attention, prompting them to come to the library to enjoy the services provided there. On the day of the grand opening, the library served more than 30,000 readers. In the past two years since opening, the Liaoning Provincial Library has received over 4 million reader-times and has hosted over 2,500 promotional reading activities such as exhibitions and lectures. The library has also developed many brand services such as "read aloud," "sign-language world," "old age club," "Children's reading Utopia," and "million-mile books".

\section{Reading Space}

Reading services is one of the basic functions of the library. The Liaoning Provincial Library has collected several types of resources such as paper (including periodicals, books, local literature, and ancient books and so on), electronic resources and video resources. There is also the new reading center, electronic reading room, preservation reading room, Chinese and foreign literature borrowing area, historical literature reading area, local literature service area, multimedia service areas, and other areas. Among them, the new book center, the historical literature reading area, and the local literature service area offers some featured service content:

1. New Book Center: The library's new purchase of classic and popular books will all be displayed in this area and updated every week. The book reading service of this section is one month earlier than for the regular books. In the past two years since opening, the new book center has shelved more than 20,000 copies of new books and has served more than 300,000 reader-times. The center's new book has not been cataloged, so it cannot be borrowed. However, the reader can make a reservation in advance and borrow the book as soon as it is shelved. To attract readers, the new book center not only provides book reading services, but according to current popular topics or industry trends, it also carries out certain small book exhibition activities. The exhibitions held at this library since its opening two years ago include the Nobel Prize for Literature, the Wenjin Book Award, the national conditions and current facts, Chinese and traditional culture, The Belt and Road Initiative, recommended books of the Liaoning Library, etc. In total, there were 23 subject book exhibitions and more than 5,000 books were exhibited;

2. Historical literature reading area: To make the ancient books come "alive" and make the readers feel the charm of excellent traditional culture, the Liaoning Province Library, using digital library technology, microfilm technology, holographic imaging technology, and other modern technical methods, designed and created three main historical reading spaces: the ancient reading room, the Republic of China literature reading area, and the 《Si Ku Quan Shu 》 series reading room. This reading area is designed with antique, solemn, elegant elements, and has nearly 200 reading seats. Books which were once too precious to be seen by the public are now available for reading. From April 23, 2017 to September 30, more than 200 readers were signed in and more than 1,000 copies of literature were provided;

3. Local literature service area: The local literature service area has the featured literature collection of the Liaoning Provincial Library. The local literature service area is a multi-dimensional space which integrates the local literature reading area, the Northeast Anti-Japanese UnitedArmy Historical Museum, the Liaoning writer's exhibition area and the Liaoning Provincial Governmental Information Disclosure Center. The local literature service area is a window of 
all-around and multi-angle show of cultural styles in the Liaoning Province. It is also an important collection of literature and a development center of the regional culture of Liaoning. The service area not only provides the retrieval, reference and consultation services of local literature, it also carries out readers' training on a regular basis every Tuesday and Thursday afternoon. From April 23, 2017 to September 30, this area has received an accumulative number of 4,200 reader-times.

\section{Learning Space}

The Liaoning Provincial Library is a knowledge organization, document preservation institution, information service center, and is also a reader's learning and communications center. Because of these features, the Liaoning Provincial Library, in addition to providing traditional reading desks and chairs everywhere, also set up a 24-hour self-help library and a shared learning space to provide readers with literature resources and physical resource services:

1. 24-hour self-service library. To extend the service time, the Liaoning Provincial Library has created a 24-hour self-serve library service space with three main features including leisure reading, self-help, and self-learning; the self-serve library offers nearly 30 thousand books with 22 categories and 52 leisure reading seats. Readers only need to carry the ID card to enjoy the "late night study" service. In the past two years of opening, the 24-hour self-help library has received more than 140,000 reader-times and more than 220,000 copies of books were borrowed.

2. Shared learning space. A shared space for learning is convenient for readers to learn, communicate, and share the physical space distributed in the literature and multimedia service areas as well as other service areas. Each physical space is generally equipped with desks and chairs for 3-6 people to have discussions and study. Readers can use this space to have activities such as interest group discussions, creative achievement sharing, and so on, according to their own learning needs.

\section{Active Space}

Carrying out varieties of readers' activities has become a trend for the public library in recent years. Preparation and exploration to facilitate these reader events have been practice building two small, and one large, lecture halls and an exhibition hall. With the help of the large number of reader activities, our library now has gained popularity in readers, enriched library services, and through the evaluations and publicity of our readers, formed some service brands. These factors have enhanced the library's social status and value. In the activities carried out in the Liaoning Provincial Library, there emerged some service brands such as "The Liaoning Provincial Library Forum" and "Children's reading Utopia," among which "Children's reading Utopia" was named the most enlightening project of the IFLA International Marketing Awards in 2017:

1. Children's World: To enrich the children's reading experience and to cope with the age of small readers, and to meet their desire for knowledge, the library created a children's reading area, toddler reading area, magic digital experience zone, toy experiences, multimedia reading area, children's language school, classics recitations, art, four-dimensional picture book reading, Toy Story, and other children's activities. On one hand, the library regularly held brand activities. For example, according to the school-library linkage, the "library reading calendar" themed children's activity was organized by more than 20 primary and secondary schools. This makes the library an extension of classroom learning and enhances the fun of a second classroom. From January to September 2017, 167 events were held, and the number of primary and secondary school participated came to a total of 16,000 people. Every weekend, there were 4-5 "Children's reading Utopia" activities. On the other hand, the library will also carry out some temporary activities in the winter or summer vacations. For example, every year we will host our wonderful one night at the Library parent-child event named "the Fantasy childhood" including a professional children's 
play, a large-scale parent-child activity, classic children's film appreciation, and sleeping with the books and other contents." In 2017, after the ceremony of the "Kaidik Award," a "Kaidik Award" winning picture sharing exhibition was held. Ever since the opening of the library two years ago, the Children's World has held over 500 activities, young participants reached a number of more than 120 thousand people, more than 20 exhibitions were held, and service was provided to more than 1 million people;

2. Exhibition hall: The Liaoning Provincial Library exhibition hall is a place for displaying visual effects of cultural exchanges. It regularly holds exhibitions covering history, culture, painting, calligraphy, and art. Since the opening, the exhibition hall has launched the "City memory Shenyang's old architectural sculpture painting exhibition," "Filial Love home - Jiao Bo my father and mother art works exhibition," "Iron Soul Praised in the Monument - Liaoning Province Library memorial collection exhibition of the Northeast Anti-Japanese United Army's Fourteen Years Fighting, " Book House treasure - collection of precious ancient books, " Remember the history to creating the future - to celebrate the party's $19^{\text {th }}$ meeting photo exhibition," and other large exhibitions with more than 80 sessions in total and the cumulative number of more than 1 million people who came to watch them;

3. Multi-functional lecture hall: To enable readers to obtain a rich and three-dimensional culture, the Liaoning Provincial Library built three multi-functional lecture halls that could accommodate thousands of people. The lecture halls have regularly organized various forums or reports with diverse themes, rich connoisseur celebrities, social hotspots, science lectures, and so on. With the employing of the multi-functional lecture halls, the "Liaoning Library forum" has become the cultural brand of readers. In the past two years of opening, the multifunctional lecture halls have held lectures, more than 140 reports, and received a cumulative number of more than 40,000 person-times;

4. Special group service center: To have the special groups of society enjoy the public culture services provided by the library and feel the social care and the library's warmth, the Liaoning province library created a special group (mainly refers to the blind, disabled and other groups) culture service space - special group service center. The special group service center is equipped with 4000 books, large prints of the books, 80 reading seats, as well as the blind channel, wheelchair access, disabled readers dedicated bathroom, a groove placed beside the seats for blind sticks, special lamps for weak readers, and other facilities. This area mainly carried "read aloud," "sign language world," "old age club," and other brand service activities. Among these activities, the "read aloud" activity service project won the 2016 national learning Lei Feng " 100 Best Volunteer Services" award. Opened for two years now, the special group service center has carried out more than 400 activities and has received special groups of readers to a total of 12 thousand person-times;

5. Multimedia service area: To conform to the new era of cultural life, the Liaoning Provincial Library has created a multimedia service space to integrate digital reading, audio-visual appreciation, new media experience, and innovation and entrepreneurship service. There are more than 400 seats, including an electronic reading area with 296 terminals, 116 reading seats in the audiovisual reading area, and an accumulated number of 370 thousand reader-times. At the same time, there is a professional 3D cinema, high-fidelity stereo surrounded audio room, music appreciation room, recording studio, periodical themed music appreciations, themed film appreciations, music salons, and other activities. Since the official opening in January 2016, a total of more than 600 thematic activities were held, involving more than 80,000 reader-times;

6. Wensu study room: To allow readers to find a sense of belonging in the library, to see the library as their own at home, and to enhance the flexibility of the readers' activities, the Liaoning Provincial library has created a Wensu study room and service area. This area holds rich and colorfully themed activities. For example, since the opening on April 23, 2017, this area has successfully held 10 "Wensu Study and Art Salon" activities. On September 23, 2017, this area 
held the first phase of "The Wensu Study Room of a Human Book" activity which was a sharing of knowledge from the successor of Manchu embroidery, Bayan Sulan, who used a cheongsam show to provide the readers with a visual feast and the traditional Manchu culture.

\section{Innovative Space}

The new Liaoning Provincial Library is located in the New District of Hunnan, Shenyang City, and is nearly 20 kilometers away from the urban area. The population density is lower in this area. In order to attract more readers to the library, the Liaoning Provincial Library created some creative service spaces with modern service concepts, equipped specialized hardware facilities, and aimed at the development of innovative ideas, such as the public creative space, digital reading experience areas, and recording studios. Not only does the use of these spaces inspire users to be more innovative, they also carried out services such as creative exchanges, recording, and other value-added services which overall enhances the quality of the library services:

1. The public creative space: Following the trend of innovation-driven social development and improvement, the Liaoning Provincial Library opened a creative space covering a total of seven service functions, such as integrated intelligent conference, guest office, intellectual learning, innovation practice, intelligent output, data retrieval and sharing discussion. This creative space equipped with a wide range of 47-inch four-lead screens and four computer desktop split screens to one machine, laser light keyboard, somatosensory system and listening system, other software, box graphics workstations, industrial grade resin powder 3D printer, and other high-tech hardware. In addition to providing the physical space, hardware equipment, literature search, and other services, the library also provides the readers with knowledge mining, creative exchanges, policy advice, patent applications, product information releases, and other services. The creative space officially opened on August 28, 2016. Since then, it has attracted more than 20 groups and individuals including the 80's opera club, Duomi children's book, Oriental creative customized tailoring studio, and Shenyang Borui Future Technology Co., Ltd. At the same time, in order to stimulate the readers' innovative ideas, the Liaoning Provincial Library also uses the creative space to carry out certain activities from time to time. So far, the library has already carried out a scientific toy experience class, 3D printing experiences, magic classroom activities, and more with a total of 30 activities and more than 1,500 participants;

2. Digital reading experience area: To attract more readers into the library and allow them to experience the latest reading and learning technologies, the Liaoning Province Library built a digital reading experience area. The experience area is equipped with 4 sets of virtual reality equipment, 1 set of intelligent librarians, and 10 reading seats. It mainly provides digital technology experiences such as digital reading, intelligent librarian navigation, teaching robot demonstrations, and VR library virtual scene reading. This area officially opened to the public on January 1, 2017, and a total of 10 major VR themed experiences have been held and more than 6,000 readers came to experience it;

3. Recording studio: To give music lovers and music artists creativity, communication, experience, and display platforms, the Liaoning Provincial Library created a multi-track studio including a control room, a recording room, a data organizing room, and a waiting room. The space is equipped with highly professional recording equipment, and high-definition video production recording systems to meet a variety of music, instrumental music, voice recording, and post-production requirements. On July 2017, the official launch of the reader recording experience services and group recording services occurred. This studio has served the Shenyang Urban Construction College's welcome ceremony, a music school with violin playing activities, the Liao figure audiobook, volunteer activities, and other recording services 8 times, with 47 people, a total recording time of over 60 hours, and a total of 500 minutes for the recordings of documents; 
4. Areas and services coming soon: In addition to all these service areas in the library, the newly built Lifting Academy, studio, and other innovative service spaces have not yet opened to the public. Lifting Academy is a platform for the traditional Chinese culture lover to study and learn the broad and profound Chinese culture. After the future reconstruction of the Lifting Academy, we will set up forums, establish classics recitation classrooms, and conduct experiencing activities, build a museum and other measures. The studio will use advanced technical means, facilities, and equipment to record all kinds of video courses, celebrity interviews, and through the internet, provide personalized extended services for readers.

Liaoning Provincial Library is a public cultural service organization functioning on cultural heritage, document preservation, and information services and social education. From the view of the services offered by all these designed areas, they are multi-types and multi-features from different spaces: reading spaces, learning spaces, etc. Meanwhile, from the point of re-design of the service spaces, the Liaoning Provincial Library has also created network service spaces and digital service spaces. An example would be the establishment of the Liaoning Provincial People's Learning Center. This is a digital educational platform in the form of online learning which has multiple functions such as management of your learning progress and monitoring of your improvements. However, since the content discussed in this paper focuses on physical space redesigning, it is not detailed here.

\section{SUCCESSFUL EXPERIENCES AND DEVELOPMENTS OF SPACE RECYCLING IN THE LIAONING PROVINCIAL LIBRARY}

\section{Practical Experience}

In the process of digitalization and network development of traditional society, the traditional library has no absolute advantage in information service. However, by virtue of their popularity in services within the readers and their innovation in space reconstructions, the Liaoning Provincial Library has obtained rich achievements, praise, and has also accumulated certain success experiences:

1. Service concept: The concept of innovation and practice of a high degree of unity. One of the foundations of the successful realizations of space reconstruction of the Liaoning Provincial Library is that the whole library is fully aware of the innovative ideas of "open and low cost, coordination and mutual assistance, integration, facilitation and all elements" of innovation space. Therefore, in the planning and opening of the library, the Provincial Library has continued to uphold the concept "innovation, sharing, open, equal" as a guidance to the concept of the library. The physical layout of the new library and the service functions on its designs has further enriched and enhanced the library's service content and its social role and value of existence. This shows how the library is actively participating in the constant changes and transformations of society;

2. Service content: With innovative management thinking to drive the conversion of service mode. The Liaoning Provincial Library has successfully transitioned their managing style away from traditional time management and position management to value management, goal management, and self-management within the activity spaces. Ever since the beginning of the physical space designing stage, the library has been exploring the different management policies for all the different rooms and spaces in the library. In the end, we developed specification rules "The Standard of Residence in creative Spaces of Liaoning Provincial Library" and "The Responsibilities of the positions in the public creative space" as well as other norms to avoid overtime, unclear costs, management confusion, and other issues that may arise from the space use and management of the library. Through the protection of the normalized system, it has enhanced the efficiency and effectiveness of services. This innovative service management thinking drives the process of transitioning of its content from resource services and social education to 
creative exchanges of customized information, thought enlightenments, and value realizations. Such as the creation of space services, the library does not just simply provide a 3D printer and other hardware equipment, but makes the settlement of the enterprise (founder), institutional cooperation, brainstorming, and other services to stimulate the creative, or even ordinary user's interests to innovation. This has allowed the guests to become more knowledgeable and creative as well as providing space for communication and technology. Ultimately, this has helped to achieve technology application exchanges, creative sharing of inspirations, and inspirations of new ideas through communications;

3. Service strategy: To promote the activities of services, and to make services become a brand. Although the new library of Liaoning Province is located in the new district of Shenyang, the population density is low and the distance to the urban area is far. These objective factors restrict the number of readers in the library. However, the Liaoning Provincial Library, through activities to promote the service, has made the service become a part of its brand. In its past two years since opening, the library has attracted more than 4 million reader-times through more than 2,500 reader activities. Some activities with extensive social impacts and reader praising have gradually become the Liaoning Provincial Library's service brand, such as "read aloud," "sign language world," "Children's Reading Utopia," "drama appreciation seasons" "million books Miles," and so on. These brand services have also received extensive praise from the industry. For example, "Children's Reading Utopia" has held more than 400 times activities with a variety of forms, such as picture book sharing, classics recitation, handmade activities, drama games, toy experience, cultural bazaar, and provides diverse experience for children readers. The total number of participants accumulated to 20,000 and there have been more than 100 reports from Liaoning TV, Liaoning Daily, NetEase news, and other traditional Medias, as well as new Medias. On April 19, 2017, "Children's Reading Utopia” won one of the most enlightening projects of the IFLA International Marketing Awards (Table 1);

4. Service support: Adequate funding and first-class resource allocation. The space service of the new library of Liaoning not only has the features of a modern library such as of the reading, learning, activeness, innovations, and other service spaces, it also has first-class facilities, equipment, staff, other hardware configurations, and adequate funding (Table 2).

Table 1. Activity reports of the Liaoning Provincial Library since opening

\begin{tabular}{|c|c|c|c|c|c|}
\hline $\begin{array}{l}\text { Type of } \\
\text { Activity }\end{array}$ & $\begin{array}{c}\text { Reading Promotion } \\
\text { Category }\end{array}$ & $\begin{array}{c}\text { Digital Experience } \\
\text { Category }\end{array}$ & $\begin{array}{l}\text { Innovative } \\
\text { Category }\end{array}$ & $\begin{array}{c}\text { Volunteer Service } \\
\text { Category }\end{array}$ & Entertainment Category \\
\hline $\begin{array}{l}\text { Form of } \\
\text { Service }\end{array}$ & $\begin{array}{l}\text { 1. "Children's } \\
\text { Utopia" like } \\
\text { brand activities. } \\
\text { For example, the } \\
\text { Liaoning book } \\
\text { center, Toy Story, } \\
\text { Children plays, } \\
\text { Four - dimensional } \\
\text { picture book } \\
\text { reading, creative } \\
\text { finger reading; and } \\
\text { more } \\
\text { 2. Exhibitions, } \\
\text { lectures; } \\
\text { 3. Human Book }\end{array}$ & $\begin{array}{l}\text { 1. VR reading } \\
\text { experience; } \\
\text { 2. VOD video on } \\
\text { demand service; } \\
\text { 3. Digital resource } \\
\text { promotion } \\
\text { activities. For } \\
\text { example, Database } \\
\text { use training, Online } \\
\text { prize knowledge } \\
\text { contest, and more }\end{array}$ & $\begin{array}{l}\text { 1. Successful } \\
\text { presentation } \\
\text { activities; } \\
\text { 2. Wensu Room } \\
\text {.Art salon; } \\
\text { 3. Sound } \\
\text { recording service }\end{array}$ & $\begin{array}{l}\text { 1. Older reader's } \\
\text { activities. Examples: } \\
\text { old age club, English } \\
\text { salon, Elderly } \\
\text { computer classes, } \\
\text { and more.; } \\
\text { 2. Special group } \\
\text { service. For example, } \\
\text { sign language world } \\
\text { and read aloud }\end{array}$ & $\begin{array}{l}\text { 1. Opera music appreciation } \\
\text { season activities, including } \\
\text { listening, painting, watching } \\
\text { the classics; } \\
\text { 2. "Liaoning provincial } \\
\text { Library's Cinema" movie } \\
\text { reading activities } \\
\text { 3, Music appreciations, film } \\
\text { appreciations; }\end{array}$ \\
\hline $\begin{array}{l}\text { Number } \\
\text { of Events }\end{array}$ & 634 & 452 & 31 & 1206 & 204 \\
\hline
\end{tabular}


Table 2. Hardware configurations of the sections of the Liaoning Provincial Library

\begin{tabular}{|c|c|c|c|c|}
\hline $\begin{array}{l}\text { Service } \\
\text { Space }\end{array}$ & Service Facilities & Service Content & Service Time & $\begin{array}{l}\text { Service } \\
\text { People }\end{array}$ \\
\hline $\begin{array}{l}\text { Creative } \\
\text { Space }\end{array}$ & $\begin{array}{l}\text { 1. Intelligence meeting area: } 1 \text { set of } 47 \text {-inch four-lead screens } \\
\text { and four computer desktop split screens to one machine } \\
\text { 2. Creative Working Area: } 20 \text { sets of laser light keyboards, } \\
\text { somatosensory system and listening systems, other software } \\
\text { 3. Learning Area: } 12 \text { units of Desktop Integrations of the } \\
\text { country's more important library and mainstream information } \\
\text { 4. Innovative Practice Area: One Boxx graphics workstation, } 15 \\
\text { Dell graphics processing displays } \\
\text { 5. Intelligence Output Area: US imported industrial grade resin } \\
\text { powder 3D printer, US imported Maker II desktop wired 3D } \\
\text { printers and HP laser color printers both one each } \\
\text { 6. Information Access Area: } 100 \text { HP computers, } 61 \text { Domestic } \\
\text { and foreign databases and real-time information literature source } \\
\text { databases } \\
\text { 7. Sharing and Discussion Area:3 High tables and } 12 \text { high chairs }\end{array}$ & $\begin{array}{l}\text { Into the customer } \\
\text { service: Founder } \\
\text { office, product testing, } \\
\text { Online learning, } \\
\text { Platform design, 3D } \\
\text { printing, Results show, } \\
\text { Information Releases, } \\
\text { and other public services } \\
\text { (Sunday of every last } \\
\text { week of every month): } \\
\text { Space visiting, Creative } \\
\text { training, 3D printing } \\
\text { experience }\end{array}$ & $\begin{array}{l}\text { Open daily for } \\
\text { entries; } \\
\text { Everyday } 8: 30-17: 00\end{array}$ & 3 People \\
\hline $\begin{array}{l}\text { Music } \\
\text { Appreciation } \\
\text { Room }\end{array}$ & $\begin{array}{l}\text { Audiovisual Room:7.1 Channel speaker and JVC3D projector } \\
\text { set } \\
\text { Listening Room: Acapella sound with music tour amplifier, Pan } \\
\text { Wang phonograph set }\end{array}$ & $\begin{array}{l}\text { Music appreciation } \\
\text { activities }\end{array}$ & $\begin{array}{l}\text { Every Tuesday and } \\
\text { Friday, 13:30-14:30, } \\
\text { WeChat public } \\
\text { number appointment } \\
\text { registrations }\end{array}$ & 2 People \\
\hline $\begin{array}{l}\text { Film } \\
\text { Appreciation } \\
\text { Room }\end{array}$ & $\begin{array}{l}\text { American JBL Extreme Series } 7.2 \text { channel speaker set, JVC } \\
\text { high-definition projector, JVC original 3D glasses and } 2.35: 1 \\
\text { high-definition projection screen, Panta magic deformation lens }\end{array}$ & Film appreciations & $\begin{array}{l}\text { Every Monday, } \\
\text { Thursday, and } \\
\text { Saturday 13:30- } \\
\text { 15:30, WeChat } \\
\text { public number } \\
\text { appointment } \\
\text { registrations }\end{array}$ & 2 People \\
\hline $\begin{array}{l}\text { Recording } \\
\text { Studio }\end{array}$ & $\begin{array}{l}\text { HP servers, Multiple effects device, Reverb affect device, } \\
\text { Single channel amplifier, Multi - channel amplifier, and other } \\
\text { professional recording equipment and a set of operating systems, } \\
\text { a variety of audio production systems and voice processing } \\
\text { software }\end{array}$ & $\begin{array}{l}\text { Reader recording } \\
\text { experience, Group } \\
\text { recording service }\end{array}$ & $\begin{array}{l}\text { Officially Opens to } \\
\text { the public on July } \\
2017 \text {, No regular } \\
\text { service times }\end{array}$ & 2 People \\
\hline $\begin{array}{l}\text { Children's } \\
\text { World }\end{array}$ & $\begin{array}{l}\text { Magic Digital Experience Zone: } 6.5 \text { meters long, } 2.5 \\
\text { meters wide radar touch graffiti wall1;7 meters long 3D } \\
\text { animated interactive ground game; } 4 \text { sets of box-360-degree } \\
\text { somatosensory game } ; 4 \text { projection book voice explanations }\end{array}$ & $\begin{array}{l}\text { The three - dimensional } \\
\text { experience of digital } \\
\text { reading }\end{array}$ & Everyday 11:00-15:00 & 6 People \\
\hline
\end{tabular}

\section{Development Thinking}

The Liaoning Provincial Library, in keeping up with the pace of development of the times and the state, has made achievements in recognition of the construction of public cultural services and the spirit of "double creation" and an innovative service concept. Through the reconstruction of the internal space of the library, Provincial libraries also need to actively explore the following aspects of space recycling:

1. How to achieve the integration and interaction of multi-dimensional spaces inside and outside the public library. A one-stop community service centre or an on-spot service or experience is beneficial to the readers of the library. This drives the future of public library space recycling and will no longer be limited to the original single organization and single functional range (Kun, 2015). Together, multiple libraries like this idea in order to make diverse, functional integration and convenient one-stop space service centers become a trend. For the Liaoning Provincial Library, how to realize the integration and interaction of the internal and external space of the library, such as the one-stop service of multiple service spaces, and the interactive advantages of multiple spaces are all problems that need to be solved in the future;

2. How to achieve the public library's innovation space's multiple attributes of expression and delivery. The future development trend of public library space reconstructions are development 
processes, trends of culture, communication, and innovation. This has become increasingly prominent and eventually will become the main attribute (Gang, 2016). How to make the library reconstruction space with multiple attributes and multiple channels, be three-dimensional, have high-efficiency expression and delivery, accessible to users, and receive social recognition will also be challenging;

3. How to achieve the unity of an industry organization function and the government function. The emergence of the innovative society, including public libraries, which is a public cultural service organization, has allowed building innovative service spaces become the norm. However, from the perspective of the development of the public library, it is necessary to guide and plan the rational allocations of various public library resources in the region and the whole country to form a distinctive service space group with reasonable characteristics and a reasonable layout. To improve the developmental relation between the industry organization functions, such as the China Library Association, the Liaoning Library Society, and the government, functions needs to have good coordination, as well as the attention, support, participation, and multi-way explorations from the library, government, and the community;

4. How to successfully improve and perfect the creative incubation function. The innovation consciousness and thinking of the library innovation service space need to be provided by the library users, the founders, and so on. This is a kind of socialized resource supply (Wei, 2014). At the same time, the innovation of spaces in the library services, especially for social forces; giving them consciousness of innovation, experience, and so on. However, how to make the public library break through the social functions, administration systems, and other restrictions to achieve the innovative functions of the recycling of space in the library is yet to be solved. This is especially for the innovative spaces and their commitments to the creative incubation function. All our library people need to think about it and make efforts.

\section{CONCLUSION}

The practice of space reconstruction of the Liaoning Provincial Library has helped to achieve further innovations and developments of the library's physical service space. Additionally, this has given the library service space and cultural attributes, innovation attributes, exchange attributes, and many other attributes. This has greatly improved and enriched Liaoning province's public library service system as they helped the library's services transition from the traditional cultural heritage, knowledge aggregation, and social education to the directions of creative incubations, knowledge exchanges, leisure, and entertainment. More than two years after the opening of the Liaoning Provincial Library, we have accumulated certain successful experiences through active explorations and practices. However, the future developments of this library still need the thinking and explorations from the industry.

\section{ACKNOWLEDGMENT}

The paper is funded by grants from the general Project of the National Social Science Foundation of China (No.18BTQ020). 


\section{REFERENCES}

Administration of the State Council of the People 's Republic of China. (2017). Reply of the State Council on the Overall Urban Planning of Shenyang City. Retrieved from http://www.gov.cn/xxgk/pub/govpublic/mrlm/201011/ t20101112_62528.html

Gang, A. (2016). Sharing the economic era of cloud incubation: Operations and Management Methods of Space Innovation from Designs to Becoming a Reality. Hangzhou: Zhejiang People's Publishing House.

Kun, F. (2015). Reshaping Cultural Space: Spatial Turn of Public Cultural Service Construction. Journal of Yunnan Administration College, 17(06), 26-31.

People's Forum. (2017). How many "Big Cities" does China have. Retrieved from http://politics.rmlt.com. $\mathrm{cn} / 2014 / 1126 / 349461 . \mathrm{shtml}$

Shenyang Municipal Bureau of Statistics. (2016). Statistical Communique of Shenyang 's National Economic and Social Development in 2016. Retrieved from http://www.shenyang.gov.cn/zwgk/system/2017/09/14/010193052.shtml

Wang, X., \& Wang, T. (2017). The Practice and Thinking of Public Library Space Reclamation from the Perspective of Public Cultural Service - Taking the Liaoning Provincial Library as an Example. The Library, $4,40-43$.

Wei, C. (2014). Space behavior and behavior's space. Nanjing: Southeast University Press.

Xiaowen Wang is the director of the Liaoning Provincial Library, a research librarian and an executive director of the Library Society of China. She obtained a MA in Library Science from Liaoning University in 2003. She has published a number of academic articles in CSSCl-index journals, e.g. Library Construction, Library and Information, and Library.

Tianni Wang is a librarian at the Liaoning Provincial Library, an editor of Library Journal. She obtained a BSc in Computer Science and Technology from Jilin University in 2005 and an MSc in Quantitative Economics from Dongbei University of Finance and Economics in 2009. She was honored a Young Talents Award by the Library Society of China and has published many articles in CSSCl-index academic journals, e.g. Information and Documentation Services, Library and Information, and Library. 